\title{
René Fahr
}

\section{Job Design and Job Satisfaction - Empirical Evidence for Germany?**}

The present paper uses a large representative data set for Germany to analyze the effect of an enriched job design, which is characterized by a high degree of autonomy and multitasking, on job satisfaction. In our empirical approach we take job satisfaction as a proxy variable for workers' utility following the approach suggested in Clark/Oswald (1996). We present clear evidence that modern job design increases job satisfaction independent of worker characteristics and variations in the definition of enriched job design. We find some tentative evidence for the impact of the job design/employee-match on job satisfaction. In particular, workers whose observable characteristics match the requirements of enriched workplaces report higher job satisfaction than workers who were mis-matched to enriched workplaces.

Key words: Human Resource Management practices, job satisfaction, job design, SOEP, autonomy, multitasking (JEL: J2, J28, M5, M54)

Prof. Dr. René Fahr, Department of Management, University of Paderborn, Warburger Str. 100, D-33098 Paderborn, Germany. E-mail: rene.fahr@uni-paderborn.de.

** I am are grateful to Thomas Bauer, Ortrud Leßmann, Wenzel Matiaske, an anonymous referee and seminar participants in Cologne, and Paderborn for providing valuable comments. Patrick Mammel provided able research assistance with the preparation of an earlier draft of the paper.

Article received: September 28, 2009

Revised version accepted after double blind review: September 10, 2010. 


\section{Introduction}

Back in 2001 an OECD report emphasizes the fact that the increasing adoption of new technologies at the workplace goes along with the introduction of new workplace practices such as teamwork, job rotation schemes, employee involvement and flatter management (OECD, 2001). The statement was supported by a graph, showing that the countries with the highest expenditures for information and computer technology (ICT) as a percent of GDP in 1996 like Sweden, United Kingdom, the Netherlands and Denmark, have the highest incidence of new work practices (OECD, 2001, figure 6). Since then the share of ICT intensive occupations on total employment stabilized on a level of about 20 percent in Europe, the United States, Canada and Australia (OECD 2010). While ICT adoption should lead to the productivity enhancement of the workplace and Human Resource Management (HRM) practices are meant to facilitate this process the question arises whether the introduction of new workplace practices do have a direct productivity effect. In this spirit, Richard Peccei describes the link between Human Resource Management (HRM) and the value development of a company as the Holy Grail of the Human Resource Management research. Within that research, Peccei identifies the investigation of the influence of HRM practices on the satisfaction of the worker as a strongly neglected aspect (Peccei, 2004: 2).

While high job satisfaction is associated with higher job performance (Judge et al., 2001), low job satisfaction correlates with a higher probability of quitting (Clark et al., 1998), higher absenteeism (Drago \& Wooden, 1992) and lower productivity (Mangione \& Quinn 1975).

The impact of modern workplace practices on job satisfaction is antithetic even from the seminal literature on the topic. It is one of the basic assumptions of the Job Characteristics Model of Work Motivation (JCM) by Hackman and Oldham (1976, 1980), Kelly (1982) and Pollert (1991) that there are different reasons that employees could prefer classic organized jobs with a low degree of autonomy and a more tayloristic job design.

In the present paper we examine the effect of two important HRM practices on the job satisfaction of workers: the extension of a workplace in the vertical dimension with a higher degree of autonomy and the enhancement of a workplace in the horizontal dimension with a higher degree of multitasking. The presence of both characteristics on a workplace is designated as an enriched job design in comparison with the classic job design, where both characteristics are not given. The analysis of the effects of an enriched job design on the job satisfaction follows the economic approach of Clark and Oswald (1996) where job satisfaction is modeled as a proxy variable for workers' utility. By focusing on job satisfaction as an outcome variable we complement other approaches which relate job enrichment to other employee outcomes (Berlinger et al., 1988).

Despite the broad literature on empirical job design research surveyed in Parker and Wall (1998) and Guest (2002) there are only few studies which have explored the relation between modern workplace practices and job satisfaction with larger multifirm data sets. Clark (1999) uses data from the International Social Survey Program (ISSP) for, 1997 in order to examine the question for 19 OECD countries; Bauer 
(2004) bases his analysis of the effect of "High Performance Workplace Characteristics" on data from the European Survey on Working Conditions (ESWC). Similar to the present study, Bauer creates an index of modern workplace design. Kalmi and Kauhanen (2008) investigate the impact of different workplace specifications on different job outcomes with data for Finland. The study by Mohr and Zoghi (2008) comes closest to the present paper. The authors test the effect of Job Enrichment on the job satisfaction with the Canadian study "Workplace and Employee Survey" (WES) from the years, 1999 and 2001. Their concept of job enrichment is broader than in the present paper. Besides the fact that Mohr and Zoghi (2008) are able to investigate into the issue of causality with their two-year panal data they address the same question as in the present paper; namely, whether the impact on job satisfaction from job enrichment is different for workers with different suitability for modern workplace practices. In particular, Mohr and Zoghi investigate separate samples for unionized and nonunionized employees assuming that unionized employees have a preference for a classic job design. In fact, their results do not differ for both samples.

The present paper contributes in the following aspects to the literature. We are able to investigate the question of the impact of an enriched job design on job satisfaction with a large representative data set for Germany. To the knowledge of the author this is the first detailed analysis on the relation between job design and job satisfaction for Germany. We define enriched job design with the help of only three questions on the vertical and horizontal extension of the workplace. This approach allows us to measure the intensity of the practices in an index and therefore in a second step to verify the robustness of the results at variation of the threshold value for enriched job design. Moreover, we can align our results to a very specific definition of enriched job design. In line with Mohr and Zoghi (2008) we try to directly address the question whether enriched job design increases job satisfaction for different kind of workers. To this end, we use an empirical approach which follows the basic idea of propensity score matching, however in a much simpler framework. The approach taken in the present paper will therefore not only analyze if job design per se contributes to an increase of job satisfaction but also if the accurate matching of a worker to an enriched or a classical job design affects the job satisfaction. In particular, the analysis of this question has an important implication for business strategy. While previous studies could only state if HRM practices in general raise job satisfaction, this paper can answer the question if this applies principally to all jobs and the corresponding workers of a company.

\section{Job design and job satisfaction}

\section{Definition}

Job design describes the characteristics and working conditions of a workplace in a broader scope. In a narrow sense and also as part of this study, job design will be seen as describing features of the workplace which relate to the content of the job.

In particular, we will distinguish enriched from classic or tayloristic job design. Job enrichment thereby refers to the enrichment of the workplace because of diversified tasks and autonomous job designs. This definition of enriched job design is re- 
lated to "innovative" or "new" job design"1 (Bauer, 2004) or work practices. These modern or high involvement work practices address the composition of the workplace based on psychological aspects.

The conventional work organization relates however more to specialized or even monotonic work with less autonomy. The term "specialized" may not be mixed with the term "qualified" because "specialized" describes the concentration on a certain narrowly defined kind of work or task. In particular, it does not evoke a special qualification needed. Further dimensions of the work organization, which are not considered here, relate to 1) tasks which can be integrated to a single workplace, 2) skills and abilities, which are demanded for the fulfillment of a job, 3) the required education or 4) the level of cooperation and communication during the work performance.

\section{The Association of Job Design and Job Satisfaction}

The evaluation of the correlation of job design and job satisfaction is not consistent in the literature. While the JCM postulates a sophisticated relation between job design and job satisfaction moderated by growth-need strength, it has been the received opinion in the later seventies to see in the renunciation of the tayloristic workplace concepts a positive effect on the job satisfaction of workers under all circumstances (Parker \& Wall, 1998). This perception was powered by overall high need strength scores in empirical tests of the JCM (Hackman \& Lawler, 1971). Marmot et al. (1991) find in their comprehensive analysis of public employees in London (Whitehall II Study) that employees with a higher hierarchic position show, despite the associated stress, a better health condition and a higher job satisfaction compared with employees in lower hierarchic positions. However, Kelly (1982) and Pollert (1991) allege different reasons that employees could prefer classic organized jobs. The assumption that characteristics of modern job design do not necessarily have a positive impact on job satisfaction is supported by the study of ergonomists who prove an increased workplace risk on modern job design (Askenazy, 2001; Fairris \& Brenner, 2001; Brenner et al., 2004). Modern work practices might lead to a higher "intensification" of work (Green, 2004) which would lower job satisfaction. Therefore the central research question of the present paper is to determine if enriched job design has a positive impact on the job satisfaction in general. Based on the findings of Marmot et al. (1991) that the position in the job correlates with particular socio-economic characteristics, we examine furthermore if the positive impact is independent from the observed worker characteristics. A positive impact of modern job design on job satisfaction for all employees indicates that the effect is traced back just to the job design rather than to the worker characteristics. Considering workers on classic jobs, differences in the job satisfaction of workers who are suited or have a preference for classic job design according to their characteristics and those who rather appear to be predestinated for an enriched job design can be interpreted as following. A higher job satisfaction for "unsuited" workers compared with workers who are suited for a classic job design indicates that the defining characteristics for enriched job design effect a high job satisfaction independently from the actual design of the job. Is the job satisfaction of "un- 
suited" worker lower compared with those, who are suited for the classic job design, there would be evidence that the matching of the employee and the type of job design is determining for the satisfaction of workers.

\section{Data and empirical strategy}

The present study uses data of the German Socio-Economic Panel (SOEP) for 2001 (SOEP Group, 2001). In this year detailed information concerning work conditions and job design were inquired. The SOEP is an annual representative household survey of households and persons in Germany. Besides the detailed information concerning the earnings situation and the occupational environment of the interviewee the data set contains also information concerning the satisfaction with different life contexts and therefore is especially suitable for the examination of the present question. The detailed information about job satisfaction has often been used in studies on this topic (e.g. Clark et al., 1998; Hamermesh, 2001). The sample used for the empirical analysis is restricted to workers, who are aged younger than 65 and provide information concerning their job satisfaction. In particular, we exclude not employed, people in education, unemployed, pensioners, apprentices, trainees, interns and people in military or community service. Of the total sample of 22,351 individual respondents in the 2001 wave of the SOEP we are left with 4272 observations for the empirical analysis of which 3545 provide wage information and are included in the estimates to explain job satisfaction.

As most of the other studies on this topic, we use cross-sectional data. Questions on job design have been asked in the SOEP in the waves 1985, 1987, 1989, 1995 and 2001. The information in the first three of the aforementioned waves has been used in Matiaske and Mellewigt (2001) in an analysis of the dynamics of job satisfaction. Mohr and Zoghi (2008) have two-year panel data to investigate the association between job design and job satisfaction and are able to support the findings of the cross-sectional studies on the topic. We use only the most recent wave of the SOEP. Panel models like fixed effects model cannot help to resolve the identification problem in the present analysis. The object of analysis of panel model would be the impact on job satisfaction of a worker whose workplace is redesigned from a classic workplace to an enriched workplace. ${ }^{2}$ The impact on job satisfaction for a worker who passes through such a process will be different than for a worker who is hired directly on a workplace with an enriched job design (Parker \& Wall, 1998). But even such an analysis would require using panel data in consecutive years (or consecutive two-year intervals). The household data of the eighties are considered as too old for the present analysis, however.

The idea of using self-reported data on job satisfaction as an auxiliary variable for the utility out of work follows the fundamental contribution of Clark and Oswald (1996) who incorporated the concept in the economic literature for the first time. They defined an individual job satisfaction as:

$$
\mathrm{u}=\mathrm{u}(\mathrm{y}, \mathrm{h}, \mathrm{i}, \mathrm{j})
$$

2 Examples for that are promotions or the delegation of responsibility on employees. 
whereas $u$ describes the individual utility out of work, $y$ stands for earnings, $h$ for working hours, $i$ and $j$ for characteristics of a person and a job, respectively. The hypotheses concerning the influence of enriched job design on job satisfaction are examined by means of indicator variables, which indicate if a worker is categorized as working on an enriched workplace or not and if, according to his observable characteristics, he is suitable for an enriched workplace or not. A fundamental problem is that the collected data is based on subjective estimations of workers. Therefore the problem arises that workers with a satisfied general life situation are tendentially more satisfied with their work and estimate the creative leeway on their workplace, an estimation which is adopted in the enrichment index, more positive. Thereby, a positive correlation could be determined without a causal coherence between both aspects (Parker \& Wall, 1998, p. 26). The SOEP asks questions concerning the satisfaction in different domains of life. We will therefore check the robustness of our results when including other satisfaction variables as right hand side variables.

The following questions which are asked in the 2001 wave of the SOEP are used to identify an enriched workplace: the questions asking "Is your job varied?" and "Do you decide yourself how to complete the tasks involved in your work?" as part of a set of questions related to work conditions with the following options to answer: Applies to my work completely/partly/not at all. And a composite variable "Autonomy in occupational activity" (scale 1-5, low to high autonomy). The latter is a generated variable from data providers using the detailed information about the occupational position to infer the degree of autonomy (cf. Hoffmeyer-Zlotnik \& Geis, 2003 for details).

With the three variables which are related with an enriched job design, a factor analysis has been conducted. The factor analysis with respect to the Kaiser Criterion (Eigenvalue greater or equal 1) reveals a reduction to one factor. All three variables contribute with almost equal shares in the resulting index.

Table 1: Factor analysis of modern work conditions

\begin{tabular}{l|c|c|c}
\hline Factor loading & Factor 1 & Factor 2 & Factor 3 \\
\hline Varying activity & 0.5525 & 0.8041 & 0.2195 \\
\hline Autonomous job design & 0.5789 & -0.5597 & 0.5930 \\
\hline Autonomy of occupational action & 0.5997 & -0.2005 & -0.7747 \\
\hline Eigenvalue & 1.68192 & $\mathbf{0 . 7 0 7 0 4 8}$ & $\mathbf{0 . 6 1 1 0 2 9}$ \\
\hline Rate of explained variance & $\mathbf{0 . 5 6 0 6}$ & $\mathbf{0 . 2 3 5 7}$ & $\mathbf{0 . 2 0 3 7}$ \\
\hline
\end{tabular}

Note: Own calculation with data of SOEP (2001).

Corresponding to the ascertained contributions of the single dimensions which determine the "enrichment" of the workplace design, an enrichment index will be formed with the normalized variables. Workplaces are classified on the basis of the enrichment index into workplaces with enriched or with classic job design. As the determination of an index threshold value for the allocation ensues necessarily ad-hoc, three threshold values will be determined out of the observed distribution of the enrichment index. Thereby, the preferred threshold value is the index value at the 
maximum of the density function of the enrichment index outlined in figure 1 . Index values above this threshold are attributed to an enriched job design and lower index values to a classic job design. The preferred model will be estimated using two other threshold definitions as a robustness check. As an alternative concept we consider the index value of a median worker, which means the value that determines exactly half of the workers in classic designed workplaces and the other half with rather enriched designed workplaces. However, this threshold-approach assumes that workplaces can be equally classified as enriched or classic. Therefore, we will also estimate the main specification in the paper with the more conservative threshold value which identifies the upper quartile of workers in the empirical distribution of the index.

\section{Working at the enriched workplace and the job-worker match}

Our goal is now to use the observed index numbers of the enrichment index to classify all workers whether they work on an enriched job or not. Moreover, we want to find out, whether the impact of working on an enriched job is different for workers who do not have a preference or do not fit in a modern workplace. We will therefore fit a vector of certain characteristics to the observed enrichment index. This function is kind of a demand function to choose (or be suitable for) working in an enriched job design and will be used to predict an enrichment index. ${ }^{3}$ By comparing the actual enrichment index value with the predicted enrichment value for each employee we will be able to sort each individual into one of these four groups:

Enriched yes/yes (job/employee): Employees, who work within an enriched job design (enrichment index $>$ threshold) and who have a match to these work conditions according to their observed characteristics (predicted enrichment index $>$ threshold).

Enriched yes/no (job/employee): Employees, who work within an enriched job design (enrichment index $>$ threshold) but who do not match to these work conditions according to their observed characteristics (predicted enrichment index $<$ threshold).

Enriched no/yes (job/employee): Employees, who do not work within an enriched job design (enrichment index $<$ threshold) but who should work within an enriched job design according to their observed characteristics (predicted enrichment index $>$ threshold).

Enriched no/no (job/employee): Employees, who do not work within an enriched job design (enrichment index $<$ threshold) and who should not work within an enriched job design according to their observed characteristics (predicted enrichment index $<$ threshold).

3 When evaluating the predicted index at the threshold index value to determine whether a worker matched into an enriched job design, the approach is somewhat comparable to propensity score matching. Among the differences to this approach, in the present paper we simply estimate a demand function for the index value and not the probability in a discrete choice model as in the propensity score matching (cf. Caliendo \& Kopeinig, 2008). 
The empirical specification will account for all three threshold concepts: maximum, median and upper quartile. The kernel density estimate for the enrichment index and the predicted enrichment index is displayed in figure 2 and 3, respectively.

The identification of the job-employee matching crucially depends on the specification of the demand function for working within an enriched job design. Table 2 reports some of the variables included in the demand function for enriched job design. Descriptive statistics for all included variables along with a description of the variables can be found in Table A1. It is more likely to observe workers with an increasing age to work within an enriched job design with a peak at the age of 51 years and less likely thereafter. There is also a clear skill bias to work in an enriched workplace in the sense that higher schooling degrees (starting from the university entrance level leaving certificate) compared to lower secondary school correlates with enriched job design. All job status groups show a higher prevalence of enriched job design when compared to blue-collar workers. Modern workplace practices are also highly correlated with the occupational group. Among the coefficients not reported in Table 2 we find a significant positive coefficient on enriched job design compared to occupations in administration for technical occupations but a significant negative coefficient for occupations in the service and health sector. A strong positive effect in a statistical and an economic sense on working in an enriched job design is also found for being male. We found no impact from the grades in math, literature and languages in school. An additional approach to pick up the unobserved preference and suitability to work in an enriched workplace is by including information about the job status of the parents (cf. d'Addio, 2007 and the references therein). An interesting observation here is that the fact that

Figure 1: Kernel density estimate of the enrichment index along with threshold concepts

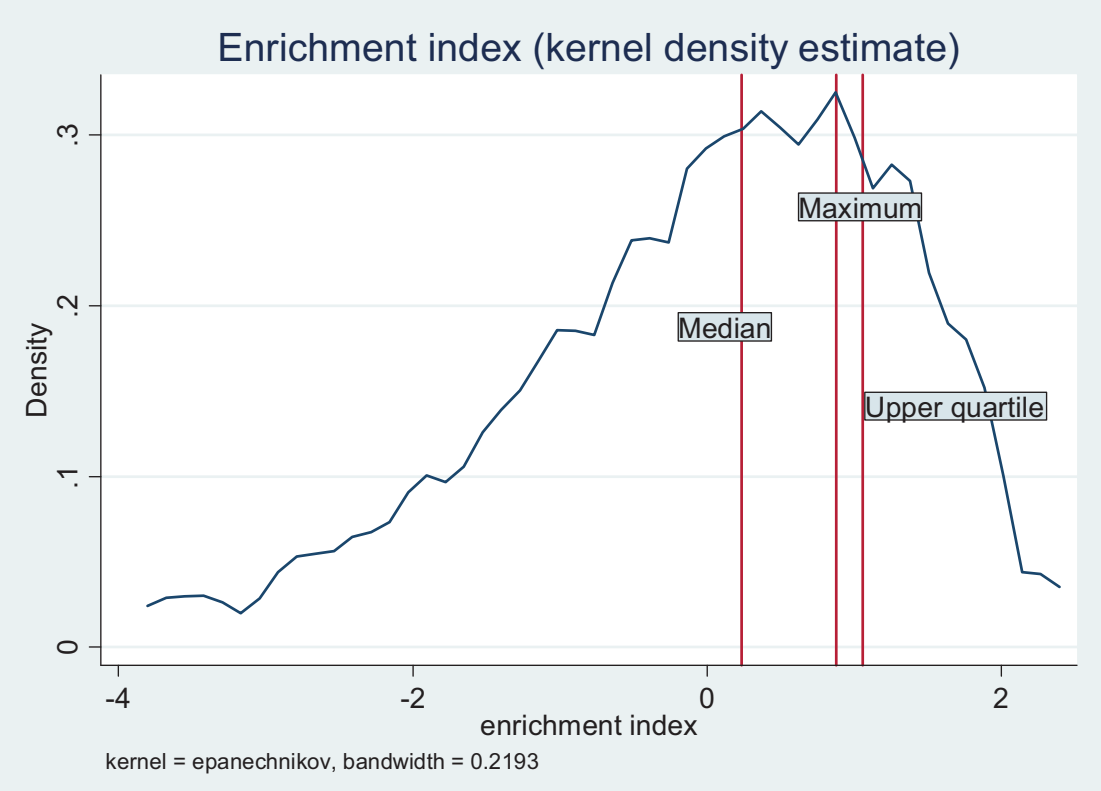


Figure 2: Kernel density estimate of the predicted enrichment index along with threshold concepts (Prediction based on estimation reported in table 2)

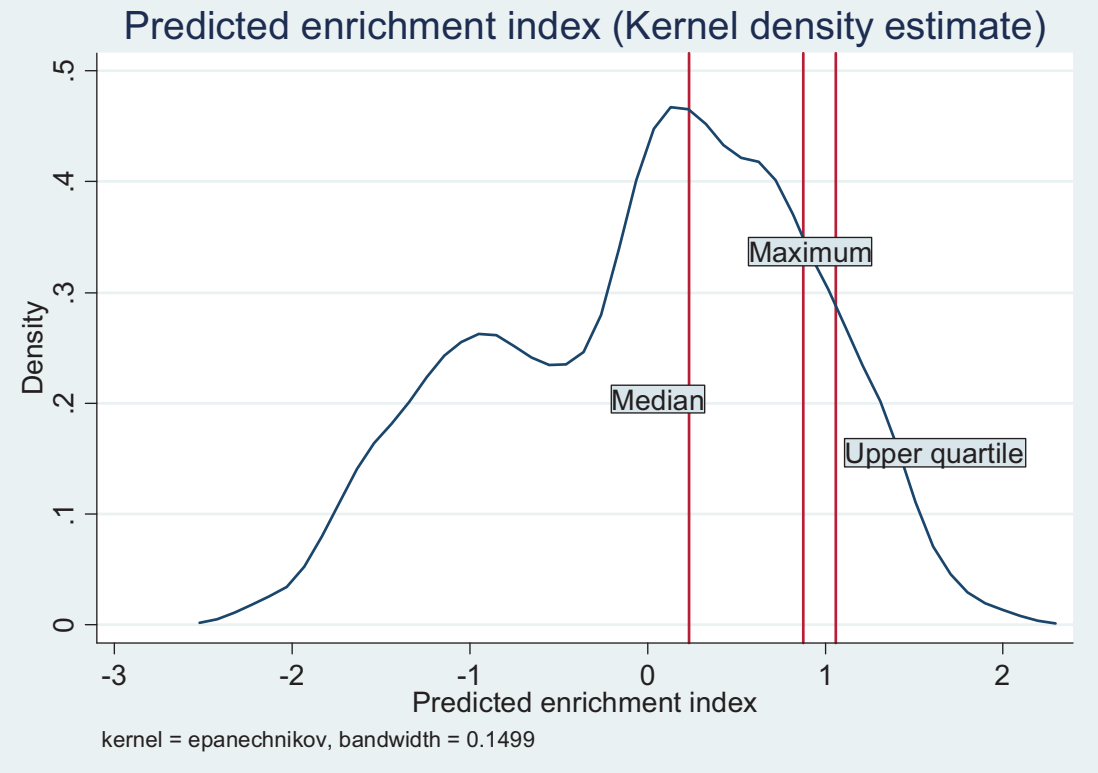

the father does not work compared to having a blue-collar worker as a father inclines the child significantly to work in an enriched workplace. Personality is certainly an important characteristic to infer the suitability to work in an enriched workplace. Moreover, personality moderates the association between job design and job satisfaction (Illies \& Judge, 2004; Judge et al., 2002). However, information concerning the personality is available only in the 2005 wave of the SOEP and we cannot assume that the work conditions stay unaltered over a period of four to five years.

\section{Empirical results}

Table 3 which is graphically displayed in figure 3 provides a first clue on how the level of job satisfaction varies within the different types of matching groups. Those groups with an enriched job design have highly significant higher average values of job satisfaction than those groups with classical job designs (two sided t-tests). This is a first remarkable result as it seems that modern workplace practices seem to unfold a positive impact on job satisfaction independent of the fact whether employees fit into the enriched job design according to their observed characteristics. Before checking the robustness of this finding in a multivariate regression analysis we want to have a deeper look whether the matching of a worker to a certain job design has an impact on job satisfaction given the job design condition (enriched or not).

When first inspecting the classical workplaces we find the average job satisfaction of the mis-matched workers to be higher with the maximum and the upper quartile threshold definition. The differences between mis-matched and matched workers are not significant, however. Only when assuming that workplaces are evenly divided into 
Table 2: Explaining the extent of an enriched workplace

\begin{tabular}{|c|c|}
\hline Variable & Index \\
\hline \multirow[t]{2}{*}{ Age } & $0.047^{* * *}$ \\
\hline & {$[0.011]$} \\
\hline \multirow[t]{2}{*}{$(\mathrm{Age})^{2} / 100$} & $-0.046^{* * *}$ \\
\hline & {$[0.013]$} \\
\hline \multicolumn{2}{|l|}{ Type of Education } \\
\hline \multirow[t]{2}{*}{ No schooling Certificate } & $-0.538^{* * *}$ \\
\hline & {$[0.070]$} \\
\hline \multirow[t]{2}{*}{ Secondary school Certificate } & -0.016 \\
\hline & {$[0.040]$} \\
\hline \multirow[t]{2}{*}{ University entrance level } & $0.167^{* * *}$ \\
\hline & {$[0.052]$} \\
\hline \multirow[t]{2}{*}{ University degree } & $0.289^{* * *}$ \\
\hline & {$[0.052]$} \\
\hline \multirow[t]{2}{*}{ Polytechnic degree } & $0.338^{* * *}$ \\
\hline & {$[0.057]$} \\
\hline \multirow[t]{2}{*}{ Male } & $0.460^{* * *}$ \\
\hline & {$[0.035]$} \\
\hline \multirow{2}{*}{$\begin{array}{l}\text { Working in occupation } \\
\text { trained }\end{array}$} & $0.382^{* \star *}$ \\
\hline & {$[0.034]$} \\
\hline \multirow{2}{*}{ First Job } & 0.007 \\
\hline & {$[0.037]$} \\
\hline \multirow{2}{*}{ Several Job Changes } & -0.001 \\
\hline & {$[0.044]$} \\
\hline \multirow{2}{*}{ New Job since, 2000} & -0.037 \\
\hline & {$[0.041]$} \\
\hline \multicolumn{2}{|l|}{ Job status } \\
\hline \multirow[t]{2}{*}{ Civil Servant } & $1.314^{* * *}$ \\
\hline & {$[0.072]$} \\
\hline \multirow[t]{2}{*}{ White-collar employee } & $1.171^{* * *}$ \\
\hline & {$[0.049]$} \\
\hline \multirow[t]{2}{*}{ Self-Employed } & $1.762^{* \star *}$ \\
\hline & {$[0.066]$} \\
\hline \multicolumn{2}{|l|}{ Occupational group } \\
\hline \multirow{2}{*}{ Agriculture } & -0.037 \\
\hline & {$[0.109]$} \\
\hline \multirow{2}{*}{ Production } & $-0.100^{*}$ \\
\hline & {$[0.056]$} \\
\hline \multirow{2}{*}{ Technical } & $0.174^{* * *}$ \\
\hline & {$[0.056]$} \\
\hline \multirow{2}{*}{ Service } & $-0.137^{* \star *}$ \\
\hline & [0.043] \\
\hline
\end{tabular}

\begin{tabular}{|c|c|}
\hline \multirow{2}{*}{ Public order/Safety } & -0.130 \\
\hline & {$[0.082]$} \\
\hline \multirow{2}{*}{ Health } & $-0.206^{\star \star \star}$ \\
\hline & {$[0.063]$} \\
\hline \multirow{2}{*}{ Social/Education } & $0.181^{\text {***}}$ \\
\hline & {$[0.050]$} \\
\hline \multicolumn{2}{|l|}{ Job Situation of the Father } \\
\hline \multirow{2}{*}{ Father: Not employed } & $0.234^{* *}$ \\
\hline & {$[0.092]$} \\
\hline \multirow{2}{*}{ Father: Civil servant } & -0.016 \\
\hline & {$[0.044]$} \\
\hline \multirow{2}{*}{ Father: White-collar worker } & 0.024 \\
\hline & {$[0.041]$} \\
\hline \multirow{2}{*}{ Father: Self-Employed } & -0.012 \\
\hline & {$[0.052]$} \\
\hline \multicolumn{2}{|l|}{ Job Situation of the Mother } \\
\hline \multirow{2}{*}{ Mother: Not employed } & 0.007 \\
\hline & {$[0.039]$} \\
\hline \multirow{2}{*}{ Mother: Civil servant } & -0.061 \\
\hline & {$[0.062]$} \\
\hline \multirow{2}{*}{ Mother: White-collar worker } & 0.042 \\
\hline & {$[0.045]$} \\
\hline \multirow{2}{*}{ Mother: Self-Employed } & 0.012 \\
\hline & {$[0.083]$} \\
\hline \multicolumn{2}{|l|}{ Performance in School } \\
\hline \multirow{2}{*}{ German grade: good } & 0.032 \\
\hline & {$[0.039]$} \\
\hline \multirow{2}{*}{ Math grade: good } & 0.033 \\
\hline & {$[0.035]$} \\
\hline \multirow{2}{*}{ Foreign language: good } & -0.009 \\
\hline & {$[0.046]$} \\
\hline \multirow{2}{*}{ Certificate: good } & 0.070 \\
\hline & {$[0.056]$} \\
\hline Number of observations & 4272 \\
\hline $\mathrm{R}^{2}$ & 0.4673 \\
\hline
\end{tabular}

Note: Own calculations with data of SOEP (2001). Robust standard errors in parentheses. ${ }^{*},{ }^{* *},{ }^{* * *}$ denotes significance at the $10 \% ; 5 \%$ und $1 \%$ level, respectively. Reference groups are lower secondary school, no academic degree, blue collar worker. In addition 6 indicator variables for firm size are included. 
the categories enriched and classic job design (median threshold) we find that those who match to classic workplaces according to their observed characteristics are weakly significantly happier than those who should not work within a classic job design according to the observed characteristics $(t=1.9141, \mathrm{p}=0.056$, two-sided). With reference to workplaces with an enriched job design we find no significant happiness differences between matched and mis-matched workers when using the "median" as the threshold definition. This is different for our preferred "maximum" threshold definition and the "upper quartile" definition which both impose stronger requirements than the "median" threshold condition for defining a workplace as enriched. Those workers who should work within an enriched job design report a weakly significant higher mean value of job satisfaction ( $\mathrm{t}=1.9146, \mathrm{p}=0.0558$, two-sided) according to the "maximum" threshold condition and a significantly higher mean value of job satisfaction according to the "upper quartile" definition ( $\mathrm{t}=2.3921, \mathrm{p}=0.017$, two-sided). The latter result could be explained by the fact that the characteristics which qualify workers for enriched workplaces lead to a higher job satisfaction per se. The result for classic workplaces according to the median threshold provides some evidence for the relevance of the correct match for job satisfaction.

Table 3: Mean values of job satisfaction using different thresholds defining an enriched workplace

\begin{tabular}{l|c|c|c|c}
\hline Threshold definition & $\begin{array}{c}\text { Enriched yes/yes } \\
\text { (job/worker) }\end{array}$ & $\begin{array}{c}\text { Enriched yes/no } \\
\text { (job/worker) }\end{array}$ & $\begin{array}{c}\text { Enriched no/yes } \\
\text { (job/worker) }\end{array}$ & $\begin{array}{c}\text { Enriched } \\
\text { no/no (job/worker) }\end{array}$ \\
\hline Maximum & 8.00 & 7.80 & 7.24 & 7.17 \\
N & 462 & 788 & 254 & 2768 \\
Median & 7.69 & 7.74 & 6.82 & 7.06 \\
N & 1498 & 754 & 375 & 1645 \\
Upper Quartile & 8.19 & 7.86 & 7.36 & 7.26 \\
N & 264 & 412 & 227 & 3369 \\
\hline
\end{tabular}

Note: Own calculations with data of SOEP (2001).

Table 4 presents a multivariate analysis with job satisfaction as the dependent variable to investigate whether the results observed in the descriptive analysis can be supported when including other determinants of job satisfaction. In particular, we want to investigate whether the descriptive findings are just an artifact of job design and the employee-job design match is just a proxy for other important determinants of job satisfaction. 4 The variables of interest "enriched yes/yes", "enriched yes/no" and "enriched no/yes" are in the first rows of Table 4. The reference group is made up of employees who should work within a classic job design and do so ("enriched no/no"). The uneven column numbers report the result of an estimation of a parsimonious specification including only the job/employee-match indicators and the basic variables

4 Because the dependent variable is on an ordinal scale with 10 categories we also conducted an ordered logit analysis as a robustness check. Because the results are qualitatively similar and the coefficients in an ordinary least squares model are easier to interpret we report only these results. 
of the model in Clark/Oswald (1996). The estimation results of the parsimonious specification completely support the findings in the descriptive analysis. In specifications (2), (4) and (6) we include a rich set of variables on working conditions and the socioeconomic background and find clear evidence that working within an enriched job design leads to higher job satisfaction independent of the fact, whether the employee matches to the enriched job design. The coefficients are lower than in the parsimonious specifications but still economically significant. Interestingly, even the size of the coefficients is similar when using different threshold definitions for an enriched workplace. In the estimation of the preferred specification (2) and in specification (6) the coefficient of "enriched yes/yes" is almost double that of "enriched yes/no" providing tentative evidence for the importance of the job-worker match regarding workplaces with an enriched job design.

One should note however, that other work conditions have a similar and partly even stronger influence on job satisfaction than an enriched job design. If a job offers the possibility for further qualification the influence on job satisfaction is of a similar size than the influence of autonomy and task variety as reflected in the enrichment index. It is not very surprising that conflicts with the superior have a huge negative influence on job satisfaction. The influence of a higher schooling degree is insignificant or even negative for an university entrance level qualification compared to lower secondary school qualification. The evidence in the literature concerning the influence of education on job satisfaction is mixed (Vila \& García-Mora, 2005). The findings for our variables of interest are robust when including variables with other domains of life. ${ }^{5}$

Figure 3: Mean values of job satisfaction

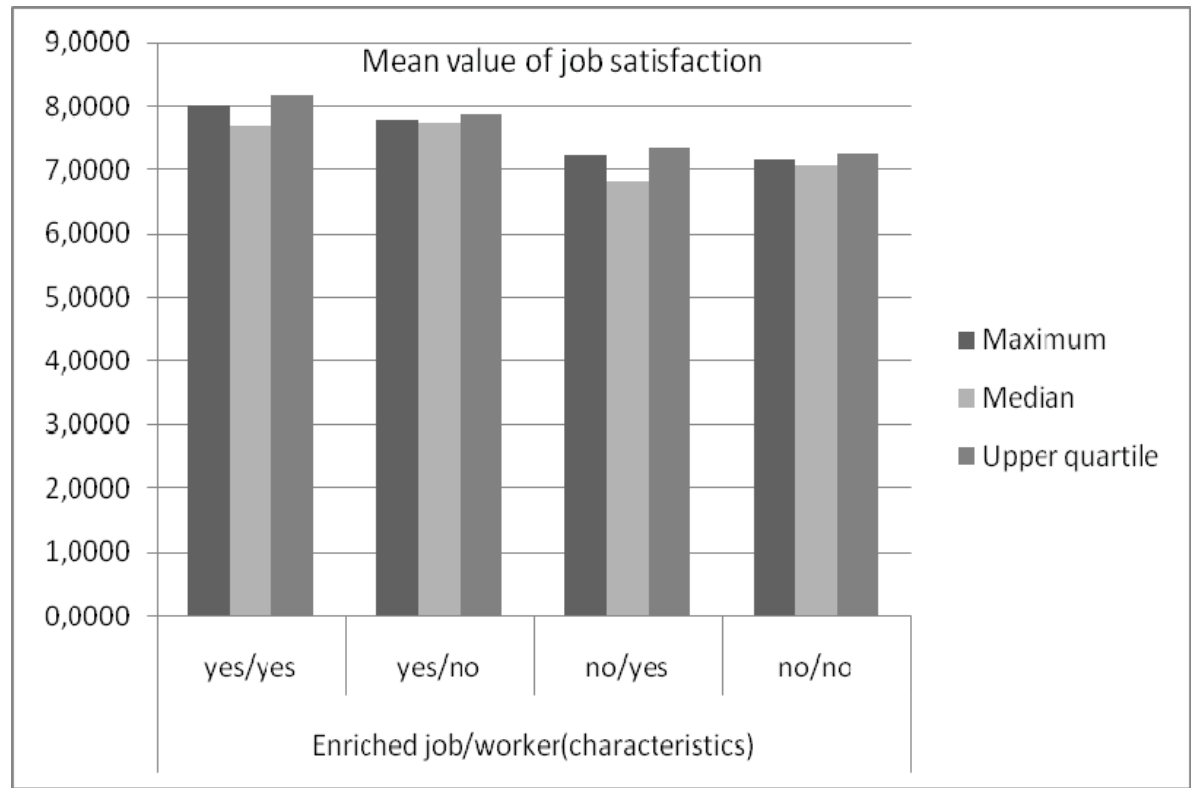

5 Results are not reported but available upon request. 
Table 4: The influence of job design on job satisfaction

\begin{tabular}{|c|c|c|c|c|c|c|}
\hline \multirow{3}{*}{ Variable } & \multicolumn{6}{|c|}{ Threshold definition } \\
\hline & \multicolumn{2}{|l|}{ Maximum } & \multicolumn{2}{|l|}{ Median } & \multicolumn{2}{|c|}{ Upper Quartile } \\
\hline & (1) & (2) & (3) & (4) & (5) & $(6)$ \\
\hline enriched yes/yes & $0.773^{\star \star \star}$ & $0.567^{\star \star \star}$ & $0.552^{* \star *}$ & $0.460^{* * *}$ & $0.795^{* \star *}$ & $0.612^{* * *}$ \\
\hline (job/ employee) (yes =1) & {$[0.107]$} & {$[0.131]$} & {$[0.086]$} & {$[0.113]$} & {$[0.130]$} & {$[0.148]$} \\
\hline enriched yes/no & $0.580^{* \star *}$ & $0.372^{\star \star \star}$ & $0.592^{\star \star *}$ & $0.409^{\star \star *}$ & $0.496^{\star \star \star}$ & $0.367^{* \star *}$ \\
\hline (job/ employee) (yes =1) & {$[0.085]$} & {$[0.086]$} & {$[0.094]$} & {$[0.093]$} & {$[0.115]$} & {$[0.118]$} \\
\hline enriched no/yes & -0.010 & 0.069 & $-0.265^{\star *}$ & -0.164 & 0.104 & 0.085 \\
\hline (job/ employee) (yes =1) & {$[0.143]$} & {$[0.157]$} & [0.131] & {$[0.135]$} & {$[0.155]$} & {$[0.170]$} \\
\hline Log Monthly Gross & $0.206^{* \star *}$ & $0.372^{\star \star \star}$ & $0.215^{\star \star \star}$ & $0.369^{\star \star \star}$ & $0.211^{* \star *}$ & $0.379^{* * *}$ \\
\hline Wage & {$[0.071]$} & {$[0.078]$} & {$[0.071]$} & {$[0.078]$} & {$[0.071]$} & {$[0.079]$} \\
\hline Actual weekly & $-0.011^{* * *}$ & $-0.008^{* *}$ & $-0.011^{* * *}$ & $-0.009^{* *}$ & $-0.010^{* * *}$ & $-0.008^{* *}$ \\
\hline working hours & {$[0.004]$} & {$[0.004]$} & {$[0.004]$} & {$[0.004]$} & {$[0.004]$} & {$[0.004]$} \\
\hline \multicolumn{7}{|l|}{ Conflicts with Principal } \\
\hline \multirow[t]{2}{*}{ (fully applies = 1) } & & $-2.342^{* * *}$ & & $-2.362^{* \star *}$ & & $-2.335^{\star \star *}$ \\
\hline & & {$[0.282]$} & & {$[0.280]$} & & {$[0.282]$} \\
\hline \multirow[t]{2}{*}{ (partly applies = 1) } & & $-1.334^{\star * *}$ & & $-1.362^{* * *}$ & & $-1.338^{\star * *}$ \\
\hline & & {$[0.088]$} & & {$[0.088]$} & & {$[0.089]$} \\
\hline \multicolumn{7}{|c|}{ Good Relations with Colleagues } \\
\hline \multirow[t]{2}{*}{ (fully applies = 1) } & & 0.133 & & 0.129 & & 0.060 \\
\hline & & {$[0.147]$} & & {$[0.146]$} & & {$[0.147]$} \\
\hline \multirow[t]{2}{*}{ (partly applies = 1) } & & $-0.389^{* *}$ & & $-0.392^{* \star *}$ & & $-0.470^{\star * *}$ \\
\hline & & {$[0.166]$} & & {$[0.164]$} & & {$[0.166]$} \\
\hline \multicolumn{7}{|c|}{ Further Qualification Through Work } \\
\hline \multirow[t]{2}{*}{ (completely applies $=1)$} & & $0.741^{* \star *}$ & & $0.662^{* \star *}$ & & $0.811^{\star \star *}$ \\
\hline & & {$[0.109]$} & & {$[0.111]$} & & {$[0.107]$} \\
\hline \multirow[t]{2}{*}{ (partly applies = 1) } & & $0.451^{* \star *}$ & & $0.394^{* \star \star}$ & & $0.477^{\star \star \star}$ \\
\hline & & {$[0.103]$} & & {$[0.104]$} & & {$[0.103]$} \\
\hline \multicolumn{7}{|l|}{ Type of Education } \\
\hline \multirow[t]{2}{*}{ No schooling Certificate } & & -0.080 & & -0.061 & & -0.082 \\
\hline & & {$[0.135]$} & & {$[0.137]$} & & {$[0.135]$} \\
\hline Secondary school & & $-0.190^{* *}$ & & $-0.190^{* *}$ & & $-0.180^{* *}$ \\
\hline Certificate & & {$[0.082]$} & & {$[0.083]$} & & {$[0.082]$} \\
\hline University entrance & & $-0.413^{* * *}$ & & $-0.402^{\star \star \star}$ & & $-0.412^{\star \star *}$ \\
\hline level & & {$[0.111]$} & & {$[0.114]$} & & {$[0.112]$} \\
\hline \multirow[t]{2}{*}{ University degree } & & 0.092 & & 0.110 & & 0.073 \\
\hline & & {$[0.111]$} & & {$[0.108]$} & & {$[0.109]$} \\
\hline \multirow[t]{2}{*}{ Polytechnic degree } & & 0.040 & & 0.057 & & 0.043 \\
\hline & & {$[0.140]$} & & {$[0.137]$} & & {$[0.137]$} \\
\hline
\end{tabular}


Table 4 continued

\begin{tabular}{|c|c|c|c|c|c|c|}
\hline Male & & $\begin{array}{l}-0.343^{\star * *} \\
{[0.094]}\end{array}$ & & $\begin{array}{l}-0.314^{* * *} \\
{[0.092]}\end{array}$ & & $\begin{array}{l}-0.369^{* * *} \\
{[0.094]}\end{array}$ \\
\hline Children in the & & 0.091 & & 0.079 & & 0.090 \\
\hline household & & {$[0.078]$} & & {$[0.078]$} & & {$[0.078]$} \\
\hline \multirow[t]{2}{*}{ Constant } & $5.899^{* \star *}$ & $4.893^{\star \star \star}$ & $5.732^{\star \star \star}$ & $4.869^{* \star \star}$ & $5.926^{\star * *}$ & $4.857^{\star \star *}$ \\
\hline & {$[0.495]$} & {$[0.685]$} & {$[0.495]$} & {$[0.686]$} & {$[0.503]$} & {$[0.689]$} \\
\hline Occupation controlled & no & yes & no & yes & no & yes \\
\hline Firm size classification & no & yes & no & yes & no & yes \\
\hline Number of observations & 3545 & 3545 & 3545 & 3545 & 3545 & 3545 \\
\hline R-squared & 0.026 & 0.176 & 0.030 & 0.179 & 0.017 & 0.174 \\
\hline
\end{tabular}

Notes: Own calculations with SOEP (2001). Dependent variable is job satisfaction. Robust standard errors in parentheses. Specifications (2), (4) and (6) include controls for 8 occupation groups and 6 firm size classifications. Further variables included in the estimates but not reported are age, age ${ }^{2}$ and indicator for the marital status. Reference groups are enriched no/no (job/employee), lower secondary school, and no academic degree, applies not at all. ${ }^{*},{ }^{* *},{ }^{* * *}$ denotes significance at the $10 \%$; $5 \%$ und $1 \%$ level, respectively.

\section{Discussion}

We find encouraging and reassuring evidence for the proponents of modern workplace practices. When assigning an employee to a workplace with an enriched job design in the sense that he has a high degree of autonomy and varied tasks this will increase the job satisfaction independent of his personal suitability for such a workplace. Our findings are in line with the other studies investigating the influence of job conditions on job satisfaction with representative data sets.

Clark (1999) finds a positive correlation between the variable "job content" and job satisfaction with data of the International Social Survey Program (ISSP) for 1997. The variable "job content" comprises autonomy at the workplace which is part of the concept of enriched job design used in the present study. Bauer (2004) used indices to identify high performance workplaces in his study using data of the Survey on Working Conditions (ESWC). Part of his high performance workplace index is the Work System Index which summaries the features autonomy, type of communication with colleges, team work and job rotation. This index is comparable to the enrichment index in the present study. Bauer (2004) finds a positive impact of the Work System Index on job satisfaction in 11 out of 15 countries. A shortcoming of his study is the fact that information concerning the socio-economic background and the overall work conditions of the employees is very limited in the ESWC.

The study closest to ours is the study by Mohr and Zoghi (2008) who investigate the effect of job enrichment on the job satisfaction with a representative Canadian employee survey. Mohr and Zoghi define job enrichment based on eight characteristics, which comprise the application of employment survey, suggestion scheme among employees, information distribution concerning workplace changes, job rotation, team work, quality circle, autonomous working groups and further training. Their research question is best comparable to ours as they are interested in finding out if job enrich- 
ment might lead to lower job satisfaction for certain group of workers. The classification of workers who are suitable for enriched workplaces in Mohr and Zoghi (2008) is one-dimensional as they only classify along the dimension of union-status, imposing the questionable assumption that unionized workers have a preference for a classic job design. Mohr and Zoghi cannot support the literature on work intensification which claims that workers with a preference for classic job design will be dissatisfied with modern workplace practices. As in the present paper Mohr and Zoghi only find evidence that the positive impact on job satisfaction from enriched job design is less strong for the unionized (mis-matched workers) than for the non-unionized workers (matched workers). In this respect the results in the present paper and in the study by Mohr and Zoghi are comparable. While there is an overall positive impact on job satisfaction from modern job design for all workers, the positive impact on job design is greater for workers who match to modern workplace according to their preferences or characteristics. While we used a comparatively narrow definition of enriched job design our results are comparable to studies using a much broader definition of a modern job design. Our definition of job/employee matching groups building on the predicted enrichment index is prone to criticism but our approach performs quite well in comparison to the available approaches in the literature. A particular advantage of our approach is the fact that it easily encompasses additional variables which might serve as a proxy for the preference for enriched job design.

\section{Conclusion}

In the present analysis we investigated the effect of job enrichment in the sense of enhancing the job design in the vertical dimension (autonomy) and the horizontal dimension (task variety) on job satisfaction. We find clear evidence that enriched job design increases the job satisfaction of all employees. This finding is independent of the definition which we will use to define an enriched workplace. We were able to support the finding of Mohr and Zoghi (2008) that even employees who seem not to fit into an enriched workplace according to their observed characteristics report higher job satisfaction when working in an enriched workplace. We do not find evidence in favor of the literature on job strain and work intensification (Green, 2004) which would predict a negative effect on job satisfaction from enriched job design. This is good news for human resource strategy and the benefits of job enrichment for all groups of workers. Thereby they could build on the job satisfaction-productivity link (Judge et al., 2001) which would imply that happier employees working in enriched workplaces are more productive irrespective of whether they fit to these workplaces according to the preferences or characteristics. But we find some evidence that the impact on job satisfaction for workers whose observable characteristics match the requirements of enriched workplaces is higher than for mis-matched workers. Further research along these lines might investigate the effects of modern workplaces on employee outcomes and firm productivity when taking the matching of the employees to these workplaces into account. The future availability of even more detailed data sources and other statistical approaches to identify the unobservable suitability of workers to modern workplaces might be fruitful avenues to answer these research questions. 


\section{References}

Askenazy, P. (2001). Innovative Workplace Practices and Occupational Injuries and Illnesses in the United States. Economic and Industrial Democracy, 22(4), 485-516.

Bauer, Th. (2004). High Performance Workplace Practices and Job Satisfaction: Evidence from Europe. RWI Mitteilungen, 2003/2004 (1), 57-85.

Berlinger, L. R., Glick, W. H., \& Rodgers, R. C. (1988). Job enrichment and performance improvements. In J. P. Campell \& R. J. Campell (Eds.), Productivity in Organizations. San Francisco: Jossey-Bass.

Brenner, M. D., Fairris, D., \& Ruser, J. (2004). Flexible work practices and occupational safety and health: Exploring the relationship between cumulative trauma disorders and workplace transformation. Industrial Relations, 43, 242-266

Caliendo, M., \& Kopeinig, S. (2008). Some Practical Guidance for the Implementation of Propensity Score Matching. Journal of Economic Surveys, 22(1), 31-72.

Clark, A. E. (1999). What Makes a Good Job? Evidence from OECD Countries. In S. Bazen, C. Lucifora, \& W. Salverda (Eds.), Job Quality and Employer Behaviour. Palgrave, 11-30.

Clark, A. E., \& Oswald, A .J. (1996). Satisfaction and Comparison Income. Journal of Public Economics, 17, 95-121.

Clark, A. E., Georgellis, Y., \& Sanfey, P. (1998). Job Satisfaction, Wage Changes and Quits: Evidence from German Panel Data. Research in Labor Economics, 17, 88-101.

d'Addio, A. C. (2007). Intergenerational Transmission of Disadvantage: Mobility or Immobility Across Generations? A Review of the Evidence for OECD Countries. OECD Social, Employment and Migration Working Papers No. 52, Paris.

Drago, R., \& Wooden, M. (1992). The determinants of labor absence: economic factors and workgroup norms across countries. Industrial Labor Relations Review, 45(4), 135-141.

Fairris, D., \& Brenner, M. (2001). Workplace Transformation and the Rise in Cumulative Trauma Disorders: Is There a Connection? Journal of Labor Research, 22 (1), 15-28.

Green, F. (2004). Why Has Work Effort Become More Intense? Industrial Relations, 43 (4), 709-741.

Guest, D. (2002). Human Resource Management, Corporate Performance and Employee Wellbeing: Building the Worker into HRM. Journal of Industrial Relations, 44, 335-358.

Hackman, J. R., \& Lawler, E. E. (1971). Employee Reactions to Job Characteristics. Journal of Applied Psychology, 55, 259-286.

Hackman, J. R., \& Oldham, G. R. (1976). Motivation through the Design of Work: Test of a Theory. Organizational Behaviour and Human Performance, 16, 250-286.

Hackman, J. R., \& Oldham, G. R. (1980). Work Redesign. In E. H. Schein, \& R. Beckhard. (Eds.), Addison-Wesley Series: Organization Development. Reading, MA

Hamermesh, D.S. (2001). The Changing Distribution of Job Satisfaction. Journal of Human Resources, 36 (1), 1-30.

Hoffmeyer-Zlotnik, J. H. P., \& Geis, A. J. (2003). Berufsklassifikation und Messung des beruflichen Status/ Prestige. ZUMA-Nachrichten 52(27), 125-138.

Illies, E., \& Judge, T. A. (2004). An Experience-Sampling Measure of Job Satisfaction and Its Relationships with Affectivity, Mood at Work, Job Beliefs, and General Job Satisfaction. European Journal of Work and Organizational Psychology, 13 (3), 367-389.

Judge, T. A., Heller, D., \& Mount, M. K. (2002). Five-Factor Model of Personality and Job Satisfaction: A Meta-Analysis. Journal of Applied Psychology, 87 (3), 530-541.

Judge, T. A., Thoresen, C. J., Bono, J. E., \& Patton, G. K. (2001). The Job Satisfaction-Job Performance Relationship: A Qualitative and Quantitative Review. Psychological Bulletin, 127(3), 376-407.

Kalmi, P., \& Kauhanen, A. (2008). Workplace Innovations and Employee Outcomes: Evidence from Finland. Industrial Relations, 47(3), 430-459.

Kelly, J. E. (1982). Scientific Management, Job Redesign and Work Performance. London: Academic Press.

Mangione, T., \& Quinn, R. P. (1975). Job Satisfaction, Counter-productive Behaviour and Drug Use at Work. Journal of Applied Psychology, 60, 114-116. 
Marmot, M. G., Smith, G. D., Stansfield, S., Patel, Ch., North, F., Head, J., White, I., Brunner, E., \& Feeney, A. (1991). Health Inequalities among British Civil Servants: The Whitehall Study II. Lancet, 337, 1387-1393.

Matiaske, W., \& Mellewigt, T. (2001). Arbeitszufriedenheit: Quo vadis? Die Betriebswirtschaft, 61(1), 7-24.

Mohr, R. D., \& Zoghi, C. (2008). High-Involvement Work Design and Job Satisfaction. Industrial and Labor Relations Review, 61(3), 275-296.

OECD (2001). The New Economy: Beyond the Hype. Final Report on the OECD Growth Project. Paris.

OECD (2010). OECD Information Technology Outlook 2010. Paris.

Parker, S., \& Wall, T. (1998). Job and Work Design: Organizing Work to Promote Well-Being and Effectiveness. Thousand Oaks.

Peccei, R. (2004). Human Resource Management and the Search for the Happy Workplace. Inaugural Addresses Research in Management Series. Erasmus Research Insitute of Management.

Pollert, A. (1991). The Orthodoxy of Flexibility. In A. Pollert (Ed.), Farewell to Flexibility? Oxford: Basil Blackwell.

SOEP Group (2001). The German Socio-Economic Panel (GSOEP) after more than 15 years - Overview. In E. Holst, D. R. Lillard, \& T. A. DiPrete (Eds.), Proceedings of the 2000 Fourth International Conference of German Socio-Economic Panel Study Users (GSOEP2000), Vierteljahrshefte zur Wirtschaftsforschung, 70 (1), 7-14.

Vila, L. E., \& García-Mora, B. (2005). Education and the Determinants of Job Satisfaction. Education Economics, 13(4), 409-425.

\section{Appendix}

Table A1: Descriptive statistics for samples and variables in the estimation of the modernity index

\begin{tabular}{l|l|l|l}
\hline Variable & Description & Mean & Standard Deviation \\
\hline Age & & 42.01498 & 10.1364 \\
\hline (Age)2/100 & & 18.67981 & 8.59607 \\
\hline No schooling Certificate & $\begin{array}{l}\text { Other graduation/ Left school without/ still in } \\
\text { school education (yes=1) }\end{array}$ & 0.0807584 & 0.2724957 \\
\hline Secondary school Certificate & (yes=1) & 0.3363764 & 0.4725247 \\
\hline University entrance level & University entrance level leaving certificate & 0.2530431 & 0.4348063 \\
\hline University degree & $\begin{array}{l}\text { Degree of university/ technical university, also } \\
\text { abroad (yes=1) }\end{array}$ & 0.1697097 & 0.3754215 \\
\hline Polytechnic degree & Polytechnic degree (yes=1) & 0.0777154 & 0.2677545 \\
\hline Firm size: 5-20 empl. & Dummy (yes=1) & 0.1633895 & 0.369764 \\
\hline Firm size: 20-100 empl. & Dummy (yes=1) & 0.1985019 & 0.3989187 \\
\hline Firm size: 100-200 empl. & Dummy (yes=1) & 0.0915262 & 0.2883897 \\
\hline Firm size:, 200-2000 empl. & Dummy (yes=1) & 0.2029494 & 0.4022423 \\
\hline Firm size: >2000 empl. & Dummy (yes=1) & 0.201779 & 0.4013751 \\
\hline Male & Dummy (yes=1) & 0.5587547 & 0.496594 \\
\hline Working in occupation trained & $\begin{array}{l}\text { Working in the occup. } \\
\text { where apprenticeship } \\
\text { training received } \\
\text { (yes=1) }\end{array}$ & 0.5756086 & 0.4943081 \\
\hline
\end{tabular}


Table A1 continued

\begin{tabular}{|c|c|c|c|}
\hline First Job & (yes=1) & 0.2368914 & 0.4252249 \\
\hline Several Job Changes & $($ yes=1) & 0.1786049 & 0.3830659 \\
\hline New Job since, 2000 & Start of the job since, 2000 (yes=1) & 0.1919476 & 0.3938782 \\
\hline Civil Servant & $\begin{array}{l}\text { Civil servant status independent from hierar- } \\
\text { chical level (yes=1) }\end{array}$ & 0.0772472 & 0.2670145 \\
\hline White-collar worker & $\begin{array}{l}\text { White collar status independent of hierarchical } \\
\text { level (yes=1) }\end{array}$ & 0.5224719 & 0.4995532 \\
\hline Self-Employed & $\begin{array}{l}\text { Self-employment independent of degree of self- } \\
\text { employment (yes=1) }\end{array}$ & 0.102294 & 0.30307 \\
\hline \multicolumn{4}{|l|}{ Job Situation of the Father } \\
\hline Father not employed & $\begin{array}{l}\text { Father not employed, } \\
\text { in Education or Unemployed, Sick }\end{array}$ & 0.0273876 & 0.1632293 \\
\hline Father: Civil servant & $\begin{array}{l}\text { Civil servant status independent of hierarchical } \\
\text { level (yes=1) }\end{array}$ & 0.1853933 & 0.3886618 \\
\hline Father: White-collar worker & $\begin{array}{l}\text { White collar status independent of hierarchical } \\
\text { level (yes=1) }\end{array}$ & 0.2134831 & 0.4098139 \\
\hline Father: Self- Employed & $\begin{array}{l}\text { Self-employment independent from degree of } \\
\text { self-employment (yes=1) }\end{array}$ & 0.1184457 & 0.323173 \\
\hline \multicolumn{4}{|l|}{ Job Situation of the Mother } \\
\hline Mother: Not employed & $\begin{array}{l}\text { Mother not employed, } \\
\text { in Education or Unemployed, Sick }\end{array}$ & 0.4201779 & 0.4936451 \\
\hline Mother: Civil servant & $\begin{array}{l}\text { Dummy variable for civil servant status of the } \\
\text { mother independent from the hierarchical level } \\
\text { (yes=1) }\end{array}$ & 0.0943352 & 0.2923287 \\
\hline Mother: White-collar worker & $\begin{array}{l}\text { Dummy variable for the white collar status of } \\
\text { the mother independent of hierarchical level } \\
\text { (yes=1) }\end{array}$ & 0.2148876 & 0.4107925 \\
\hline Mother: Self-Employed & $\begin{array}{l}\text { Dummy variable for self-employment of the } \\
\text { mother independent from the degree of self- } \\
\text { employment (yes=1) }\end{array}$ & 0.0339419 & 0.181101 \\
\hline German grade: good & $\begin{array}{l}\text { Dummy variable (yes=1) for grade } 1 \text { and } 2 \\
\text { [scale: } 1-6 \text {, whereas } 1 \text { :excelent and } 6 \text { : fail] }\end{array}$ & 0.4129213 & 0.4924166 \\
\hline Math grade: good & $\begin{array}{l}\text { Dummy variable (yes=1) for grade } 1 \text { and } 2 \\
\text { [scale: } 1-6, \text { whereas } 1 \text { :excelent and } 6 \text { : fail] }\end{array}$ & 0.4389045 & 0.4963114 \\
\hline Foreign language: good & $\begin{array}{l}\text { Dummy variable (yes=1) for grade } 1 \text { and } 2 \\
\text { [scale: } 1-6, \text { whereas } 1 \text { :excelent and } 6 \text { : fail] }\end{array}$ & 0.3120318 & 0.463377 \\
\hline Certificate: good & $\begin{array}{l}\text { Dummy variable (yes }=1 \text { ) for sum of grades in } \\
\text { German, Math and Foreign language smaller } \\
\text { than } 7\end{array}$ & 0.3171816 & 0.4654333 \\
\hline Number of Observations & 4272 & & \\
\hline
\end{tabular}

Note: Own calculations with data of SOEP (2001). Indicator- (dummy-) variables are marked with (yes=1). 
Table A2: Descriptive statistic for sample and variables in the estimation of job satisfaction

\begin{tabular}{|c|c|c|c|}
\hline Variable & Description & Mean & Standard Deviation \\
\hline Log (monthly gross wage) & & 8.213139 & 0.6863706 \\
\hline Actual weekly working hours & & 38.99712 & 12.36926 \\
\hline \multicolumn{4}{|l|}{ Conflict with Principal } \\
\hline (fully applies = 1) & & 0.0262341 & 0.1598534 \\
\hline (partially applies $=1$ ) & & 0.1850494 & 0.3883924 \\
\hline \multicolumn{4}{|l|}{ Good relations with Collegues } \\
\hline (fully applies = 1) & & 0.7794076 & 0.4147046 \\
\hline (partially applies $=1$ ) & & 0.1593794 & 0.3660812 \\
\hline \multicolumn{4}{|c|}{ Further qualification through work } \\
\hline (fully applies = 1) & & 0.4186178 & 0.4934021 \\
\hline (partially applies $=1$ ) & & 0.4047955 & 0.4909217 \\
\hline \multicolumn{4}{|l|}{ Firm size } \\
\hline 5-20 employees & & 0.1590973 & 0.3658184 \\
\hline 20-100 employees & & 0.1985896 & 0.3989946 \\
\hline 100-200 employees & & 0.0944993 & 0.2925634 \\
\hline 200-2000 employees & & 0.2138223 & 0.4100607 \\
\hline >2000 employees & & 0.2149506 & 0.410846 \\
\hline \multicolumn{4}{|l|}{ Type of Graduation } \\
\hline No graduation & & 0.0815233 & 0.2736756 \\
\hline Real & & 0.3447109 & 0.475341 \\
\hline Abitur & & 0.2538787 & 0.4352904 \\
\hline University degree & & 0.1703808 & 0.3760201 \\
\hline College degree & & 0.0767278 & 0.2661966 \\
\hline Married & $\begin{array}{l}\text { Dummy variable (yes=1) for "married and living to- } \\
\text { gether" }\end{array}$ & 0.6798307 & 0.4666072 \\
\hline Existing children & Dummy variable (yes=1) if at least one child existent & 0.890268 & 0.3125995 \\
\hline Age & & 41.82426 & 10.00239 \\
\hline$(\text { Age })^{2 / 100}$ & & 18.49288 & 8.44803 \\
\hline Male & & 0.5543018 & 0.4971127 \\
\hline \multicolumn{4}{|l|}{ Occupational group } \\
\hline Agriculture & Dummy variable (yes=1) for agricultural occupation & .0245416 & .1547452 \\
\hline Production & $\begin{array}{l}\text { Dummy variable (yes=1) for manufacturing occupa- } \\
\text { tion }\end{array}$ & .2073343 & .4054542 \\
\hline Technical & Dummy variable (yes=1) for technical occupation & .0685472 & .2527183 \\
\hline Service & Dummy variable (yes=1) for occupation in service & .2191819 & .4137505 \\
\hline Public order/Safety & Dummy variable (yes=1) for public order occupation & .0358251 & .1858801 \\
\hline Health & Dummy variable (yes=1) for health care occupation & .0592384 & .2361036 \\
\hline Social/Education & Dummy variable (yes=1) for social occupation & .0877292 & .2829406 \\
\hline \multicolumn{2}{|l|}{ Number of Observations } & 3545 & \\
\hline
\end{tabular}

Note: Own calculations with data of SOEP (2001). Indicator-/ (dummy-) variable are marked with "yes=1". 